\title{
Main Directions of Pedagogical Research into Video Resources and Technologies for Foreign Language Learning
}

\author{
(D) Nina Popova ${ }^{1}$ Dr. Sc.; Alexandra Dashkina ${ }^{2} \mathrm{PhD}$; (D) Maria Odinokaya ${ }^{3} \mathrm{PhD}$; Anna Kuzmina ${ }^{4}$ \\ Peter the Great St. Petersburg Polytechnic University ${ }^{1,2,3}$; St. Petersburg State University of \\ Telecommunications named after Prof. M. A. Bonch-Bruevich ${ }^{4}$, Russia \\ ninavaspo@mail.ru'; wildroverprodigy@yandex.ru²; \\ World.Maria@hotmail.com ${ }^{3}$; kuzminaania201@yandex.ru ${ }^{4}$
}

\begin{abstract}
The purpose of the paper is to study the use of video resources and video application technologies in teaching foreign languages to technical university students. Regional studies and cross-cultural communication of native speakers in video, as well as the socially significant pedagogical content of educational video materials, are most popular among teachers, whereas professionally oriented video is underestimated. The following directions of pedagogical research into the methodology of using video in foreign language studies were revealed and analysed: (1) comparison of the results of learning lexical material in groups of students listening to the same content in the "audio only" and "audio + video" modes with a clear advantage of the second group; (2) the analysis of video modes without subtitles and with bimodal captions revealing a significant advantage of the second mode; (3) review of four examples of existing technologies for classroom mode contrasting them with the proposed flipped classroom technology of independent student work with video resources using VideoAnt and MindMeister programs. In conclusion, an assumption is made about the advantage of using video materials in students' independent work. Keeping in mind technical university objectives, the most promising video research direction is technology development for enhancing the efficiency of professionally-oriented documentary video.
\end{abstract}

Keywords: technical university, video resources, video technologies, foreign language.

\section{Introduction}

Professionally-oriented foreign languages teaching in technical universities is becoming more and more focused on the use of various electronic resources. The use of authentic Internet resources for the purposes of professionally oriented foreign language teaching is of particular importance as it increases students' motivation, enhances their cognitive activity in their domain of study, and contributes to the growth of their interest in English as a foreign language (EFL). For teaching students such a complex receptive type of speech activity as listening comprehension, a university teacher can use multiple authentic video materials available on the Internet. The Internet is believed to have become a supporting medium for communication (Aladyshkin et al., 2020; Almazova et al., 2020a; 2020b; Almazova, Andreeva, Khalyapina, 2018; Odinokaya et al., 2020; Odinokaya et al., 2019). If the university has pedagogically acceptable facilities for the use of video in teaching foreign languages, video materials from the Internet can be effectively used in the classroom and beyond. In any case, the main problems that need to be solved by a foreign language teacher at a technical university are the criteria for the choice of video resources, as well as the development of a systematic methodological approach to their use in the educational process. The methodology of video resources used in a university setting can be properly selected by considering numerous research publications on this subject. The analysis and evaluation of the pedagogical studies conducted by other researchers in this area will allow us to make informed decisions about how to proceed and what steps to take in this direction.

Therefore, this review is aimed at analysing current trends in the choice of video in the educational process, considering both benefits and limitations, and identifying the main directions of pedagogical research into the features of video use in EFL teaching. The main objectives of the research are the comparison of the results of learning lexical material in the "audio only" and "audio + video" modes; the analysis of video modes without subtitles and with bimodal captions; review of four examples of existing technologies for classroom mode. The proposed flipped classroom pedagogical technology of video material actualization in the mode of independent student work will be substantiated. The relevance of this topic is due, above all, to the need for widespread use of video in the educational process owing to its obvious advantages with respect to conventional listening comprehension practices. 


\section{Methodology}

Generally, the review is based on numerous informative sources, which were selected drawing on such eligibility criteria as relevant research content, accessibility in terms of linguistic presentation and recent years of publication. The most important inclusion criteria were the descriptive analytical value and completeness of the results/finding's presentation. The publications chosen for our review provide detailed accounts of the pedagogical experiment outcomes, with the result validity proved in mathematical terms. The numbers of papers screened for the comparative analysis of each of the three forthcoming specific directions of video resource research were considered to be sufficient when the tendency under consideration was evident. To be more exact, the main selection criterion for part 1 reflecting general aspects of video use in EFL teaching, was profound authors' reflexion on the use of video resources for learning English in general, with the content preferences, advantages and limitations discussed. The period (1981-2009) embraced by us in this general part is wider than that for the more specific interest aspects covered in parts 2 and 3 . A wider period of research is necessary to have a broader background of our subject representation in the critical literature. The main inclusion criteria for parts 2 and 3 were the following: use of video resources for teaching listening comprehension to university students and/or high school students, for the research period of approximately 30 recent years (1989-2019); availability of experimental data analysis, with the number of learners involved and comparison of control vs experimental groups performance. Exclusion criteria were the following: inappropriate age group; the content is too general, no experimental data analysed.

Application of these criteria yielded 60 articles that were acceptable for inclusion in the meta-analysis, with the key words for screening being video resources, EFL teaching. The present review combines the results of numerous pedagogical studies devoted to video resource use in EFL teaching. The experimental data from representative sources were carefully collected and analysed by us to draw objective conclusions on the basis of the data under consideration. Half of the literary sources studied by us refer to the recent five-year period 2014-2019. For electronic searches, the main databases were the Scopus and Web of Science. On the basis of an analytical review of foreign and Russian publications on the topic in combination with contextual and interpretative discursive analysis, the current state and development trends in video materials use in foreign language teaching are revealed. The most developed problems and open discussion questions of the first decades of the 21 st century is studied. Examples of existing pedagogical video technologies are compared and contrasted, with a thorough analysis of the proposed flipped classroom video technology being provided as the most recent technology development in line with the research review findings. The theoretical context of the analysis is set here by recent studies and discussions and, partly, by earlier publications.

\section{Results and Discussion}

\section{Main Tendencies in the Use of Video Materials in EFL Classrooms in Terms of Video Content and Existing Limitations}

The use of video in teaching EFL is extensively investigated as an additional learning resource. The novelty in the use of video is due rather to the broad current possibilities of using authentic video resources (Bajrami, Ismaili, 2016) in the educational process. Immense video resources uploaded on the YouTube server can be used on a regular basis in EFL classes at a university, and, given the widespread use of mobile devices, can effectively complement students' independent work.

Research on the use of video materials in teaching a foreign language emphasizes their benefits for such disciplines as regional studies and cross-cultural communication (Barmenkova, 2011; Chilingaryan, Zvereva, 2017). Indisputably, authentic video resources vividly demonstrate the process of communication between native and non-native speakers providing sufficient input for the comparison of cultural realities and peculiarities of people's behaviour in various situations of intercultural communication. Thus, students are introduced to the natural language environment and communicative situations (Anderson, Baxter, Cissna, 2004); they get an idea of the way of life, traditions, and linguistic realities of the target language countries. In general, the cultural content of such video resources can be utilized to develop students' cultural and cross-cultural competencies (Sun, Wang, Cao, 2020; Cakir, 2006). 
Research gives special attention to the obvious educational dimension of some video resources. Typical examples of such video content in the EFL teaching are fragments of films of various genres, screen versions of literary works, advertising and interviews. Students have the opportunity to consider the problems of war and peace, gender and race and discuss the problems of youth, the categories of good and evil, friendship and love, justice, and responsibility. Such content contributes not only to the cognitive but also to the social and emotional development of students while learning EFL (Pisarenko, 2017): they learn to critically evaluate video content and to express their opinions. The focus on building students' social cultural competence becomes an obvious pedagogical task when such video content is used in EFL classes at any educational institution.

The idea of social norms in the target language country can be acquired most effectively through video resources: the observation and discussion of authentic video material does seem to be a valuable preparation for countless situations going from pubs and cricket matches to family reunions and business meetings, in which a learner may one day find himself (Riley, 1981). In the works D. Willis and J. Willis (Willis, 1983a; Willis, 1983b) analysed the significance of verbal and non-verbal components in language teaching and tried to systematize the use of video resources in an EFL classroom. Both articles consider the video useful for students to become confident and familiar with psychosocial aspects of a foreign language environment. Using video, the authors are aimed at moving the student from the observer/learner role towards the native-speaker/participant role. Pre-teaching and follow-up activities are illustrated with numerous examples of video-related tasks. Their papers can be perceived as giving proper background for contemporary researchers.

The use of video for the purposes of general English development increases students' motivation and opportunity to practice speaking. Due to the variety of video content and the emotional impact of its input, students get a chance to develop a personal attitude to what they see in those videos (Chilingaryan, Zvereva, 2017). The educational significance of such content is obvious: students broaden their mind, they develop a positive attitude towards native speakers; by understanding the foreign culture, they raise their awareness of the cultural differences and become more conscious citizens of their country who are able to think critically. A similar trend can be seen in the papers of foreign researchers: video resources contain mainly real-life situations that demonstrate elements of the target foreign language culture, which increases motivation and vocabulary, as well as helps to improve students' pronunciation skills (EFL learners' views). The educational series in English "Family Album, USA" which is a good example of a training video, talks about the life of the American family of Stuarts (Family Album USA..., 2020). Each of the 46 episodes is a new story of 20 minutes each. The series consists of three episodes and three digressions - grammatical explanations or explanations of cultural traditions. The course is designed for people who are at the primary and secondary levels of study. In each part of the lesson there is video and text dialogs. Examples of general purpose video include English dialogs American and English films and TV shows.

Researchers rightly believe (Zhubanova, Tukhtabayeva, 2017) that academic listening of a video series is beneficial due to the principle of authenticity, but due to the integrated communicative skills development (listening, speaking, reading, writing), and a natural connection between language and culture. An effective integration of video into classroom work ensures more active communicative training before and after watching the video. For students who study English as a foreign language, video more than audio demonstrates communicative language in a language environment and in the wide cultural context. Video provides a flexible learning setting for English learners. It can be played with the sound turned on, so that students can hear the language they speak, or, alternatively, with the sound turned off, so that students can practice their language skills by participating in a dialogue or narration. Clearly, this requires a careful selection of the video material by the teacher in terms of topic and duration as long videos on topics of no interest to the students can be demotivating and cause problems with students' attention.

Though researchers (Kuzmina, Popova, 2019; Krašna, Gartner, 2005) use video mode to teach listening comprehension, there are few emphasizing speaking skills. Interestingly enough, some researchers examine whether digital video recordings enhance learners' oral fluency skills and investigate the learners' perceptions of the use of digital video recordings in a speaking class (Santamaria, Carlos, Encalada, 2018; Rakhmanina, Kusumaningrum, 2017). For example, the results of the experiment conducted in a group of ten Turkish students, with the speaking module of the exam International English Language Testing System (IELTS) used for checking the outcome of the experiment, suggest that the incorporation of digital 
video recordings into speaking classes improved the learners' overall speaking proficiency; however, it did not lead to a significant improvement in learners' oral fluency (Göktürk, 2016). The other paper reports on a case study conducted at a Japanese national university, where nine students had to use the video recording feature on their cell phones to produce weekly video productions (Gromik, 2012). The task required that participants produce one 30 -second video on a teacher-selected topic. Observations revealed the process of video creation with a cell phone. The weekly video performances indicated that students were able to increase the number of words they spoke in one monologue. The surveys indicated that participants believed that using the cell phone video recording feature was a useful activity. An unbelievable $46 \%$ improvement in word production and a $37 \%$ increase in words uttered per second were reported. Students rated the cell phone as a tool to assist them to improve their speaking ability.

Regretfully, we were unable to find studies on video resources of a documentary nature, in which the narration of the topic is conducted by a voice-over, although such video materials, in our opinion, are especially relevant for professionally-oriented EFL in a technical university (Kuzmina, Popova, 2019). The off-screen text, first of all, is distinguished by the role of the announcer in the plot structure. The voice of the announcer becomes a guiding force around which the visual line is built up, and which performs the functions of accompanying what is happening in the frame. If the voice in a frame describes relevant events and reveals the meaning of what is happening here and now, the voice-over may come either from an observer commenting on the events, or from a person evaluating them. For documentaries, the narrator uses significantly fewer means of expression than the actors in the frame, and such limitations are related to the specific genre of the narrative. The voice over is to maintain distance without directly showing the emotional attitude to what is happening.

As far as the professional needs of engineering students are concerned, we should point out the use of visual-only videos combined with case studies as proposed by L.M. Dos Santos (2019). Unlike traditional English language learning classrooms, which incorporate both general and broad directions and materials (i.e., general training materials), the teaching and learning materials for this pilot study employed tailor-made materials that matched the professional needs of engineering students. In total, 18 visual-only videos for twelve chapters and six case studies were used, with 79 students participating in the study. As a weekly requirement, each student had to watch and comment on the visual-only video on the social media learning platform. Furthermore, each student needed to comment on at least three other peers' feedback to encourage discussion. Even though this study (Dos Santos, 2019) does not belong to the main research directions to be further described, this idea of using visual-only videos should be definitely tried in the intermediate learners' groups as it stimulates discussion replacing listening comprehension practice.

\section{Main directions of educational research into general aspects of video application in foreign language teaching}

The use of video in foreign language teaching is extensively investigated, and the main areas of research are as follows: a comparison of the results of learning lexical material in two groups of students listening to the same content in two modes: "audio-only" or "audio + video"; a comparison of the results of learning lexical material in two groups of students listening to the same content in two modes: "video without subtitles" or "video with subtitles", and in the last category of video there may be "video with subtitles in a foreign language" (captions) or video with subtitles in the students' native language; the use of video listening comprehension technologies, both conventional and involving e-learning, with the use of various instructional techniques or methods of video viewing to enhance students' mastering the vocabulary.

Let us consider these areas to determine the research niche for our contribution to this video research. Our hypothesis for the first area of research is the assumption that in view of the fact that video resources provide visual support, video is methodologically more effective than audio. As for the second area, we assume that the subtitles provide additional visual support for the students. Therefore, instructional videos with subtitles ensure more efficient learning of the lexical input. The third area seems to us the most innovative; it creates additional research opportunities.

\subsection{Research into the audio-only listening mode compared with the audio + video mode}

As for the first area, all researchers believe that the audio-visual mode of presentation has a clear advantage over conventional listening. Audio-visual media are closer to real life, because visual cues lead to a proper contextualization of the video sequence, which contributes to the development of students' language 
guessing and greatly facilitates understanding video content. As some researchers have shown, listening comprehension is an active cognitive process, including thinking and prediction, and not deciphering a single sound because an incomplete acoustic series often requires filling in the missing information (Astorga, 2015). Understanding is also influenced by visual input and cultural knowledge, for example, the interpretation of gestures, facial expressions and the movements of lips when speaking (Baltova, 1994).

Watching a video, students receive important information not only about vocabulary and grammar, but also about intonation, rhythm, and stress. The positive effect of visual cues was, for example, confirmed by an experiment involving 53 Canadian middle school students who studied the French language. Students who watched a 15-minute clip in audio-visual mode showed results in subsequent testing almost twice as good as students who worked in "sound only" mode. In another experiment conducted at the State Islamic University of Malang with the participation of 62 second-year students of humanities, similar results were obtained: students who audited the content in the audio-visual mode showed significantly better results (Alivi, Suharyono, 2016). This data is also in good agreement with Wuttipong's study on the use of video materials in teaching listening comprehension (Woottipong, 2014), in which it was shown that the video + audio group, 41 first-year university students altogether, was $20 \%$ more efficient in mastering lexical material than the "sound only" listening group. Similar results were also obtained by C. Chen, L. Wang, L. Xu (2014), with the sample being 86 learners. The whole sample analysed in the audio-only listening mode compared with the audio + video mode equalled 242 learners, with $78 \%$ university students and $22 \%$ school students.

\subsection{Research into the problem of using subtitles in video materials}

This is currently one of the major methodological problems. Numerous studies in Russia and in other countries are devoted to it. The authors investigate the effectiveness of using bimodal subtitles in a foreign language, which reproduce foreign text video (captions), as well as translated subtitles in the students' native language (subtitles). Many studies demonstrated the positive effect of subtitles on listening comprehension (Markham, 1989; Neuman, Koskinen, 1992); Aldera, Mohsen, 2013); Hayati, Mohmedi, 2011). According to some authors M. Latifi, A. Mobalegh, E. Mohammadi (2011), the common problem of all these studies is that all of them neglected the influence of English captions and translated subtitles on improving students' actual listening skills. The direct effect of using subtitles in specific groups of students was investigated, and no attention was paid to the long-term effect of using them. There were general critical comments on the use of subtitles, the essence of which boiled down to the fact that their presence discourages students who fail to put enough effort to understand the discourse under discussion.

There is also a certain conviction that subtitles create learners' dependence because a habit of lightweight perception of a foreign language (FL) (Danan, 2004) is thus acquired. The author believes that FL learners have a negative attitude towards subtitles, especially when they first watch the instructional video, and many teachers, as a rule, are also negatively disposed towards their use. The main problem with the use of captions in a FL may be the fact that students get used to this support, and in the process of listening benefit to a lesser degree, and their auditing abilities hardly increase. The author disputes the effectiveness of subtitles in the long term and believes that the improvement of listening skills is nothing more than superficial.

Drawing on the analysis of the above papers, we can conclude about the ambiguity of opinions on the issue of using video with subtitles, and we mainly mean bimodal subtitles (FL captions). If we evaluate this issue objectively, then the benefits of FL captions are obvious for teaching the FL to students at the elementary and intermediate levels, and these benefits greatly exceed the possible negative aspects of their use. The researchers' negative opinions seem to be, more subjective since the objective trend of assessing students' mastery of new vocabulary based on video suggests the opposite. In the overwhelming majority of pedagogical studies, the results of vocabulary learning using video captions exceed the performance of groups that have audited the video without them. In the use of subtitles, there is a prevalence of bimodal subtitles, that is, English captions. The results of the research, whose authors tested the issue on fairly representative samples of students and support the use of subtitles, are presented in Table 1. 
Table 1

The effect of pedagogical experiments on the effectiveness of bimodal subtitles in English (captions) in the instructional video

\begin{tabular}{|c|c|c|c|c|}
\hline & Place of experiment & $\begin{array}{l}\text { Number of } \\
\text { participants }\end{array}$ & $\begin{array}{c}\text { Results of groups studying in subtitle } \\
\text { mode }\end{array}$ & $\begin{array}{l}\text { Authors of the } \\
\text { research, year }\end{array}$ \\
\hline Item 1 & $\begin{array}{l}\text { Multimedia } \\
\text { University, Cyberjaya, } \\
\text { Malaysia }\end{array}$ & 92 & $67 \%$ higher than in no subtitle group & $\begin{array}{l}\text { BavaHarji, Alavi, } \\
\text { Letchumanan, } 2014\end{array}$ \\
\hline Item 2 & $\begin{array}{l}\text { Alzahra Iranian Women } \\
\text { University, Tehran, Iran }\end{array}$ & 60 & $23 \%$ higher than in no subtitle group & $\begin{array}{l}\text { Ghasemboland, } \\
\text { Nafissi, } 2012\end{array}$ \\
\hline Item 3 & $\begin{array}{l}\text { Kocaeli University, } \\
\text { Izmit, Turkey }\end{array}$ & 120 & $8 \%$ higher than in no subtitle group & $\begin{array}{l}\text { Yuksel, } \\
\text { Tanriverdi, } 2009\end{array}$ \\
\hline Item 4 & $\begin{array}{l}\text { Burdur Mehmet Akif } \\
\text { Ersoy University, Turkey }\end{array}$ & 42 & Slightly higher than in no subtitle group & $\begin{array}{l}\text { Karakas, Sariçoban, } \\
2012\end{array}$ \\
\hline Item 5 & Golestan University, Iran & 45 & $43 \%$ higher than in no subtitle group & Rokni, Ataee, 2014 \\
\hline Item 6 & $\begin{array}{l}\text { Sadr Linguistic } \\
\text { Center, Isfahan, Iran }\end{array}$ & 36 & Worse that in no subtitle group & $\begin{array}{l}\text { Latifi, Mobalegh, } \\
\text { Mohammadi, } 2011\end{array}$ \\
\hline \multirow[t]{2}{*}{ Item 7} & Islamic Azad University & 44 & Higher than in no subtitle group & Etemadi, 2012 \\
\hline & Total & 439 & Higher indicators in the subtitle groups & \\
\hline
\end{tabular}

It follows from Table 1 (Kuzmina, Popova, 2019) that the research was carried out mainly in Eastern universities, in Malaysia, Iran, and Turkey from 2009 to 2014. The number of participants in all cases is sufficiently indicative to make meaningful conclusions. A total of 439 people participated in this sample, of which 197 people (45\%) were participants in experiments with the highest group results (sum of participants in positions 1,2, and 5 of the above table) who watched videos with English subtitles. Note that 162 people (37\%: the sum of participants in positions 3 and 4 of Table 1) were participants in experiments that revealed a slight excess of the performance of video-audio groups without subtitles. 44 participants (10\%: position 7) are added to the previous numbers in favour of subtitle mode. Thus, our hypothesis that subtitles in FL (English) increase the efficiency of video listening comprehension is confirmed by $92 \%$. As for the remaining $8 \%$ of the participants (position 6 in Table 1), they most likely belong to the experiment in which the control group initially had a higher level of foreign language competence.

The above researchers point out that the groups selected for the experiment had approximately the same level of foreign language skills. From the data we have cited, it becomes obvious that the experimental groups studied in the subtitle mode exceeded the no subtitle groups in mastering the new vocabulary and content of the video material. This result is, in our opinion, also quite expected since subtitles offer students more clues and support for the understanding of the video content.

Note also that the researchers unanimously prefer bimodal subtitles in English (captions) to subtitles in students' native language. In the study conducted by R. Metruk (30 students: Zilina University, Zilina, Slovakia, 2018), not two, but three groups were tested in modes (1) "no subtitles", (2) "English captions" and (3) "subtitles in the students' native language (subtitles). In all cases, group (2) had a sufficient advantage over the other two groups (Metruk, 2018).

\section{Examples of research into pedagogical video technologies enhancing EFL learning}

Having reviewed the above aspects of research into video listening comprehension teaching, let us consider the use of pedagogical technologies providing certain activities to enhance students' comprehension of video content. By pedagogical technology we mean a certain algorithm of using educational strategies to guarantee a desirable learning outcome. There are many definitions and concepts of technology in literature. Generally, education technology is a system of influence on the learner in the learning process (Arsaliev, 2015). It involves the management of the didactic process including the stages of organization and control of the activities. Technology is a theoretical pedagogical project of educational activity management. One of the key elements of education technology is students' feedback at the transitional state of the education process (Pisarenko, 2017). Audio-visual technologies may be classified into three 
classes: those using films, video courses and all other video information (Pisarenko, Arsaliev, 2016), with their effectiveness being evaluated by means of two parameters: changes in the students' competence level and their satisfaction with training methods.

A brief description of five examples of pedagogical video technologies proposed by researchers will help us decide whether or not they are applicable for technical university students and substantiate the place of the proposed flipped classroom technology in the modern technological spectrum in a university setting.

Subtitle production technology. This technology (Zanón, 2006) involves the subtitle production of selected video clips by the students themselves with the help of subtitling programs. Three examples of supporting software were Subtitle Workshop (Subtitle workshop..., 2005), Subtitul@m (Subtitul@m..., 2003) and Fab Subtitler (FAB Subtitler..., 2003), with the Subtitle Workshop being preferable to its user-friendliness and suitability for the non-expert computer user. The pedagogic technology based on subtitle production was fairly flexible and was performed in three different ways: from English dialogs to English subtitles: bimodal subtitling; from English dialogs to subtitles in the learner's mother tongue: standard subtitling; from dialogs in the learner's mother tongue to English subtitles: reversed subtitles. The technology contained warm-up activities, the subtitling activity itself, and post-activities, containing language focus, role play, and feedback. Communicative functions covered by the clips were linked conceptually and grammatically to the contents being learnt in the course. The whole technology is realized in class, with the teacher circulating around to tackle arising problems. To implement this pedagogic technology, the teacher is supposed to provide students with relevant hints concerning the subtitling theory: for example, students should know that the time limits selected for each subtitle must be taken into account when focusing on the maximum number of characters fitting each caption.

Audiovisual technology (AT) involves shooting video by students. This high school technology (Pisarenko, 2017) draws on a number of audio-visual activities in foreign language training. The pedagogical algorithms of numerous video-based activities are developed drawing on the structure of the knowledge acquisition process according to the aims of illustrative, fact-finding, studying, critical and search viewing. The stages of previewing, presentation, after-viewing, and actualization are considered in the process of AT realization.

The most interesting feature of this technology is letting students shoot their own video, with the students being free to shoot their video exactly as they like, with a foreign language becoming the language of the creative process. The students work either individually, in pairs or teams: they show their two-minute videos to the class; they see and hear how their classmates react to what they have achieved. Students' explanations of their video conceptions in a foreign language stimulate their classmates' questions, and this discussion becomes an additional source of EFL communication which contributes to the students' communicative competence as the main goal of learning foreign languages in a high school or university.

Silent and freeze-frame viewing technology. One of the classroom technologies described recently concerned the use of two techniques of silent and freeze-frame viewing (Shahani, Tahriri, Divsar, 2014; Shahani, Tahriri, 2015). Taking the advantages of video for granted, this paper examines learners` views towards this original use of video material. About $80 \%$ of the 45 high school Iranian female EFL learners at grade three and grade four announced their agreement with an effective role of watching video using different techniques, other than normal viewing in language classroom, on their listening competence outside the classroom. All respondents $(100 \%)$ seem to prefer watching through silent viewing or freeze-frame technique which was followed by some special activities other than normal viewing without any activity.

Video blogging project technology. Video blogging (Santamaria, Carlos, Encalada, 2018; Rakhmanina, Kusumaningrum, 2017; Gao et al., 2010) is a form of blogging in which video is the medium of expression. A video blog, or vlog, is defined as a blog that uses video as its main source instead of verbal text, becoming a kind of online diary. Current video blogs are essentially text blogs with externally linked videos for each entry. Video blogging offers a richer Web experience than typical text blogging because it combines movies, sound, still images, and text, increasing the input - and potentially emotions - shared with the users. Most people who have video blogs cover various topics, such as hobbies, tips, comments, and brief speeches. 
Students can be involved in video blogging as a project assignment. Such a project assignment is considered effective as it improves their personal communication skills in a foreign language. For example, teachers can give an instruction to create a short monolog for their introduction. Furthermore, students are asked to videotape their monolog, to edit it, and to upload it to the Internet in their own personal blog sites. As the result of the project, it was found that video blogging strategy was more effective than the expository strategy for teaching and learning speaking for students with higher motivation. However, it appeared that the expository strategy drawing on teachers' explanations was more effective than video blogging strategy for teaching and learning speaking for students with lower motivation.

Flipped classroom video technology (FCVT). This technology allows us to make videos much more accessible to students (Whitley-Grassi, Baizer, 2010; Mehring, 2016). The flipped classroom means that "what is traditionally done in a class is now done at home, and traditional customary homework is now done in a class" (Bergmann, Sams, 2012). In other words, the learning sequence is inverted for the general benefit of students' video listening comprehension development.

The first stage of the professionally-oriented FCVT (Kuzmina, 2019; Popova et al., 2019) includes twotime watching of the advertising video material about the American computer company CISCO (Hub, Switch..., 2020) in the VideoAnt program, when students of the Bonch University watch the video as part of their homework and simultaneously perform the teacher's tasks presented on the computer screen (VideoAnt service, 2019). These are video content questions, translation and gap filling exercises that are uploaded to the instructor to monitor and evaluate students on the MOODLE virtual platform. The VideoAnt system tasks are aimed at developing listening skills, paying attention to details.

The second stage of professionally-oriented content visualization involves creating a mind map in MindMeister program (Online Mind Mapping..., 2020) to represent the professional content on a diagram and prepare to render the video in English. The mental map indicates not only the elements of the video content that are important for rendering the video, but also keywords in a foreign language. Thus, in this task, writing is partially practiced as a type of speech activity. The third stage is aimed at rendering the content of the professionally-oriented video clip on the mental map in English and recording the learner's own video for the teacher's control. The video report is necessary to ensure that the students do not read the entire video script, but reflect it briefly using a mental map created by them, which prepares students for communication and playing lexical games during the class.

Completing our review of EFL teaching with the use of video resources for university / high school students, we should note that there are certain articles, comprehensive as they are, which are not quite relevant to our research as they do not meet the above criteria. M. Krašna and S. Gartner (2005), for example, consider a more specific use of video technology for the exchange of teaching practices, with a remote-control camera used to record the trainee's lesson to minimize the disturbance effect. Another example of very specific technology use is given in the article of the Chinese authors (Jeng et al., 2008) involved in the use of an innovative system referred to as the Dynamic Video Retrieval System, which uses information retrieval techniques to examine video scripts for specific collocations. Another group of researchers (Kuo, Lai, Yu, 2009) investigated the multimedia environment in two groups of third-grade students in the elementary school in Taiwan. Even though the research is detailed and well-presented, the target audience does not meet our age criterion. Certain technologies, on the one hand, are described too generally, without specifying definite details of video application (Jin, Qian, 2017) for teaching, which makes them inappropriate for further analysis. The others, on the other hand, like networked video courseware systems, turn out to be too technical for an average university professor of English to implement (Zhu et al., 2015). These five examples demonstrate the obvious variety of video resource applications at different levels of EFL-competence and for different target audiences.

\section{Conclusions}

Many researchers in Russia and abroad recognize the great educational potential of video resources, which, by creating visual support for students, are more effective in teaching listening to a foreign language than ordinary audio resources. The main trend of choosing video resources for secondary schools and universities is the use of general content video for general English courses. In high school and universities, video resources contain mainly real-life situations that demonstrate elements of a foreign language culture. These situations, when native speakers appear in the frame, clearly 
demonstrate their authentic features, speech and etiquette features, which increase the motivation and vocabulary of students, as well as help to improve their pronunciation skills. Researchers note the educational value of cultural linguistic content: students become more erudite, they develop a positive attitude towards native speakers and an understanding of foreign culture, they become conscious citizens of their country who are able to think critically. As for the use of professionally-oriented documentary video in teaching a foreign language, when the speaker's voice sounds behind the scenes, this aspect is not described in the literature we have studied, although it requires our attention.

First, noted in the literature, the direction of pedagogical research, methods of video use is mainly focused on comparing the results of learning lexical material in two samples of students who listen to the same content in the "sound only" or "audio + video" modes. The results of the lexical tests after listening convincingly proved the advantage of the second listening mode using the video sequence.

The second direction of pedagogical research on the use of video, which is represented by a larger number of researchers, is devoted to identifying the role of subtitles. Comparing the results of learning lexical material in two groups of students who listen to the same content in two modes "video without subtitles" or "video with subtitles" proves the advantage of listening to video with subtitles. At the same time, a video with bimodal subtitles in a foreign language (captions) demonstrates an advantage over video with subtitles in the students' native language (subtitles).

The third direction is the development of pedagogical technologies aimed at enhancing foreign language learning. We have reviewed the subtitle production technology, audio-visual technology involving shooting video by students, silent and freeze-frame viewing technology and video blogging project technology. All these technologies have been positively evaluated by us as innovative and are worth trying out at foreign language university classes. The main limitation of these technologies is that they are mostly class work oriented and require more time for realization than is affordable in our foreign language syllabi.

The newly developed flipped classroom technology applied in Bonch Technical university of St. Petersburg (Russian Federation), lacking computer classes and the necessary number of classroom hours, seems to us a good way out when learning such a complex receptive type of speech activity as video listening comprehension. When conducting regular work on mastering vocabulary based on the VideoAnt program tested in the educational process, this technology for student independent work is likely to be recommended for widespread use in teaching foreign languages at a technical university or college, especially now, when distance learning has become dominant in pandemic conditions.

The example we have given of using a professionally-oriented documentary video, when the speaker's voice sounds behind the scenes, also represents a certain degree of novelty in the study of video listening comprehension in foreign language teaching. The shift in emphasis from the classroom to the independent work of students in mastering the video content that we offer corresponds to the real situation in Russian universities, in which the teaching and pedagogical conditions for mastering foreign languages in a class are not always optimal. Generally speaking, it can be finally concluded that in view of technical university objectives, the most promising video research direction is technology development for enhancing the efficiency of professionally-oriented documentary video presentation.

\section{Bibliography}

1. Aladyshkin I.A., Kulik S.V., Odinokaya M.A., Safonova A.S., Kalmykova S.V. (2020). Development of Electronic Information and Educational Environment of the University 4.0 and Prospects of Integration of Engineering Education and Humanities. In Z. Anikina (Ed.), Integrating Engineering Education and Humanities for Global Intercultural Perspectives. IEEHGIP 2020. Lecture Notes in Networks and Systems, 131. Cham: Springer, 659-671. doi: 10.1007/978-3-030-47415-7_70

2. Aldera A.S., Mohsen M. A. (2013). Annotations in captioned animation: Effects on vocabulary learning and listening skills. Computers \& Education, 68, 60-75. doi: 10.1016/j.compedu.2013.04.018

3. Alivi J.S., Suharyono S. (2016). Obtaining Listening Comprehension by Using Video Materials. Exposure, 5(1), 14-21. Retrieved from https://journal.unismuh.ac.id/index.php/exposure/article/view/811 
4. Almazova N., Andreeva S., Khalyapina L. (2018). The Integration of Online and Offline Education in the System of Students' Preparation for Global Academic Mobility. In D. Alexandrov, A. Boukhanovsky, A. Chugunov, Y. Kabanov, O. Koltsova (Eds.), Digital Transformation and Global Society. DTGS 2018. Communications in Computer and Information Science, 859. Cham, Germany: Springer, 162-174. doi: 10.1007/978-3-030-02846-6_13

5. Almazova N., Bernavskaya M., Barinova D., Odinokaya M., Rubtsova A. (2020a). Interactive learning technology for overcoming academic adaptation barriers. In Z. Anikina (Ed.), Proceedings of the Conference Integrating Engineering Education and Humanities for Global Intercultural Perspectives. EEHGIP 2020. Lecture Notes in Networks and Systems, 131, 786-794. doi: 10.1007/978-3-030-47415-7_84

6. Almazova N., Rubtsova A., Odinokaya M., Bernavskaya M. (2020b). Formation of professional competence of the future computer engineer in a technical University. In V. Dislere (Ed.), The Proceedings of the International Scientific Conference Rural Environment. Education. Personality (REEP), 13. Jelgava: Latvia University of Life Sciences and Technologies, 25-31. doi: 10.22616/REEP.2020.002

7. Anderson R., Baxter L.A., Cissna K.N. (Eds.). (2004). Dialogue: Theorizing Difference in Communication Studies. Thousand Oaks: SAGE Publications. doi: 10.4135/9781483328683

8. Arsaliev S. (2015). New information technologies in ethnopedagogical process. In the Proceedings of the International Conference Application of Information and Communication Technologies (AICT), 9. Rostov-on-Don, Russia: IEEE. 595-599. doi: 10.1109/ICAICT.2015.7338630

9. Astorga E.D. (2015). The relationship between listening proficiency and speaking improvement in higher education: Considerations in assessing speaking and listening. Higher Learning Research Communications, 5(2), 34-56. doi: 10.18870/hlrc.v5i2.236

10. Bajrami L., Ismaili M. (2016). The role of video materials in EFL classrooms. Procedia-Social and Behavioral Sciences, 232, 502-506. doi: 10.1016/j.sbspro.2016.10.068

11. Baltova I. (1994). The impact of video on the comprehension skills of core French students. Canadian modern language Review, 50(3), 507-531. doi: 10.3138/cmlr.50.3.507

12. Barmenkova O.I. (2011). Use of video materials for the formation of the communicative competence of students in English classes. Experiment and innovation at school, 5, 75-79.

13. BavaHarji M., Alavi Z. K., Letchumanan K. (2014). Captioned Instructional Video: Effects on Content Comprehension, Vocabulary Acquisition and Language Proficiency. English Language Teaching, 7(5), 1-16. doi: 10.5539/elt.v7n5p1

14. Bergmann J., Sams A. (2012). Flip your classroom: Reach every student in every class every day. International Society for Technology in Education

15. Cakir I. (2006). The use of video as an audio-visual material in foreign language teaching classroom. Turkish Online Journal of Educational Technology, 5(4), 67-72. Retrieved from http://www.tojet.net/articles/v5i4/549.pdf

16. Chen C., Wang L., Xu L. (2014). A study of video effects on English listening comprehension. Studies in Literature and Language, 8(2), 53-58. doi: 10.3968/4348

17. Chilingaryan K., Zvereva E. (2017). Methodology of flipped classroom as a learning technology in foreign language teaching. Procedia-Social and Behavioral Sciences, 237, 1500-1504. doi: 10.1016/j.sbspro.2017.02.236

18. Danan M. (2004). Captioning and subtitling: Undervalued language learning strategies. Meta: Journal des traducteurs/Meta: Translators' Journal, 49(1), 67-77. doi: 10.7202/009021 ar

19. Dos Santos L.M. (2019). English language learning for engineering students: application of a visual-only video teaching strategy. Global Journal of Engineering Education, 21(1), 37-44. Retrieved from http://www.wiete.com.au/journals/GJEE/Publish/vol21no1/05-DosSantos-L.pdf

20. Etemadi A. (2012). Effects of bimodal subtitling of English movies on content comprehension and vocabulary recognition. International journal of English linguistics, 2(1), 239-248. doi: 10.5539/ijel.v2n1p239

21. FAB Subtitler. (2003). Retrieved from https://ru.freedownloadmanager.org/Windows-PC/FABSubtitler.html (in Russian)

22. Family Album USA - Episode 1-46 Linden Street. (2020). Retrieved from https://www.learnrealeng.com/2014/04/family-album-usa-episode-1-46-linden.html 
23. Gao W., Tian Y., Huang T., Yang Q. (2010). Vlogging: A survey of video blogging technology on the web. ACM Computing Surveys, 42(4), Article No.: 15. doi: 10.1145/1749603.1749606

24. Ghasemboland F., Nafissi Z. (2012). The effects of using English captions on Iranian EFL students' listening comprehension. Procedia-Social and Behavioral Sciences, 64, 105-112. doi: 10.1016/j.sbspro.2012.11.013

25. Göktürk N. (2016). Examining the effectiveness of digital video recordings on oral performance of EFL learners. Teaching English with Technology, 16(2), 71-96. Retrieved from https://files.eric.ed.gov/fulltext/EJ1135917.pdf

26. Gromik N.A. (2012). Cell phone video recording feature as a language learning tool: A case study. Computers \& Education, 58(1), 223-230. Retrieved from https://www.learntechlib.org/p/50671

27. Hayati A., Mohmedi F. (2011). The effect of films with and without subtitles on listening comprehension of EFL learners. British Journal of Educational Technology, 42(1), 181-192. doi: 10.1111/j.1467-8535.2009.01004.x

28. Hub, Switch or Router? Network Devices Explained. (2014). Retrieved from https://www.youtube.com/watch?v=Ofjsh_E4HFY

29. Jeng Y.L., Wang K.T., Huang Y.M., Wu M.T., Hwang W.Y. (2008). Dynamic video retrieval system for English language learning. In the Proceedings of IEEE International Conference Ubi-Media Computing, 1. Lanzhou, China: IEEE, 302-307. doi: 10.1109/UMEDIA.2008.4570907

30. Jin G., Qian H. (2017). College English listening teaching under a multimedia environment. AgroFOOD Industry Hi Tech, 28(1), 664-669. Retrieved from https://www.teknoscienze.com/tks_issue/vol_281/

31. Karakas A., Sariçoban A. (2012). The Impact of Watching Subtitled Animated Cartoons on Incidental Vocabulary Learning of ELT Students. Teaching English with Technology, 12(4), 3-15. Retrieved from http://files.eric.ed.gov/fulltext/EJ1144953.pdf

32. Krašna M., Gartner S. (2005). Video for exchange of teaching practices. WSEAS transactions on information science and applications, 2(6), 805-813.

33. Kuo F.O., Lai Y.S., Yu P.T. (2009). A multimedia instructional environment for English learning. In F.L. Wan., J. Fong, L. Zhang, V.S.K. Lee (Eds.), Hybrid Learning and Education. ICHL 2009. Lecture Notes in Computer Science, 5685. Heidelberg Berlin: Springer, 309-319. doi: 10.1007/978-3-642-03697-2_29

34. Kuzmina A.V. (2019). Application of flipped classroom technology based on the VideoAnt program when teaching a foreign language at a technical college. In Proceedings of the II All-Russian Student Scientific Practical Conference "Polytechnic Spring. Humanitarian sciences", 131-135.

35. Kuzmina A.V., Popova N.V. (2019). Analysing the use of video materials in foreign language classes at modern Russian university. Society. Communication. Education, 10(2), 74-86. doi: 10.18721/JHSS.10207

36. Latifi M., Mobalegh A., Mohammadi, E. (2011). Movie subtitles and the improvement of listening comprehension ability: Does it help? The Journal of Language Learning and Teaching, 1(2), 18-29. Retrieved from https://dergipark.org.tr/en/pub/jltl/issue/22510/240625

37. Markham P.L. (1989). The effects of captioned television videotapes on the listening comprehension of beginning, intermediate, and advanced ESL students. Educational Technology, 29(10), 38-41.

38. Mehring J. (2016). Present Research on the Flipped Classroom and Potential Tools for the EFL Classroom. Computers in the schools, 33(1), 1-10. doi: 10.1080/07380569.2016.1139912

39. Metruk R. (2018). The effects of watching authentic English videos with and without subtitles on listening and reading skills of EFL learners. EURASIA Journal of Mathematics, Science and Technology Education, 14(6), 2545-2553. doi: 10.29333/ejmste/90088

40. Neuman S.B., Koskinen P. (1992). Captioned television as comprehensible input: Effects of incidental word learning from context for effects of incidental word learning from context for language minority students. Reading Research Quarterly, 27(1), 95-106. doi: 10.2307/747835

41. Odinokaya M., Andreeva A., Mikhailova O., Petrov M., Pyatnitsky N. (2020). Modern aspects of the implementation of interactive technologies in a multidisciplinary university. In A. Zheltenkov, A. Mottaeva (Eds.), E3S Web of Conferences, 164, 12011. doi: 10.1051/e3sconf/202016412011 
42. Odinokaya M., Krepkaia T., Sheredekina O., Bernavskaya M. (2019). The culture of professional self-realization as a fundamental factor of students' internet communication in the modern educational environment of higher education. Education Sciences, 9(3), 187. doi: 10.3390/educsci9030187

43. Online Mind Mapping - It all starts with an idea. (2020). Retrieved from

https://www.mindmeister.com

44. Pisarenko V. (2017). Teaching a foreign language using videos. Social sciences, 6(4), 1-21. doi: 10.3390/socsci6040125

45. Pisarenko V., Arsaliev S. (2016). Audiovisual technologies for foreign languages teaching. Application of Information and Communication Technologies. In the Proceedings of the Conference Proceeding IEEE International Conference on Application of Information and Communication Technologies (AICT 2016), 10. 7991793. Baku: IEEE doi: 10.1109/ICAICT.2016.7991793

46. Popova N., Vdovina E., Gavrilova A., Kuzmina A. (2019). Video technology for teaching foreign language speaking skills in a technical university. In L. Gómez Chova, A. López Martínez, I. Candel Torres (Eds.), The Proceedings of International Conference Education, Research and Innovation (ICERI2019), 12, Seville, Spain: IATED Academy, 9747-9757 doi: 10.21125/ICERI.2019.2381

47. Rakhmanina L., Kusumaningrum D. (2017). The effectiveness of video blogging in teaching speaking viewed from students' learning motivation. In Proceedings of the International Seminar on English Language and Teaching (ISELT-5), 5, 27-34. Retrieved from http://ejournal.unp.ac.id/index.php/selt/article/view/7980

48. Riley P. (1981). Viewing Comprehension: L'oeil ecoute. In The teaching of listening comprehension. London: The British Council, 143-156. Retrieved from https://www.teachingenglish.org.uk/sites/teacheng/files/pub_F044\%20ELT-

46\%20The\%20Teaching\%20of\%20Listening\%20Comprehension_v3.pdf\#page=144

49. Rokni S.J.A., Ataee A.J. (2014). Movies in EFL classrooms: With or without subtitles. The Dawn Journal, 3(1), 715-726. Retrieved from https://thedawnjournal.in/wp-content/uploads/2013/12/4-Dr.Seyed.pdf

50. Santamaria C.F., Carlos A.M.F., Encalada E.G. (2018). The Relationship Between the Use of Video Blogging and the Development of Speaking Skills: A Preliminary Study. In International Conference on eDemocracy \& eGovernment (ICEDEG2018), 5. Ambato, Ecuador: IEEE, 375-379. doi: 10.1109/ICEDEG.2018.8372311

51. Shahani S., Tahriri A. (2015). The impact of silent and freeze-frame viewing techniques of video materials on the intermediate EFL learners' listening comprehension. Sage Open, 5(2), 1-8. doi: $10.1177 / 2158244015585999$

52. Shahani S., Tahriri A., Divsar H. (2014). EFL Learners Views towards Video Materials and Viewing Techniques. International SAMANM Journal of Business and Social Sciences, 2(1), 42-60.

53. Subtitle workshop 2.51. (2020). Retrieved from http://subs.com.ru/page.php?al=subtitle_workshop (in Russian)

54. Subtitul@m 1.0. (2020). Retrieved from https://subtitul-m.software.informer.com/ (in Russian)

55. Sun Z., Wang Y., Cao L. (2020). An Attention Based Speaker-Independent Audio-Visual Deep Learning Model for Speech Enhancement. In Y.M. Ro (Eds), MultiMedia Modeling. MMM 2020. Lecture Notes in Computer Science, 11962. Cham: Springer, 722-728. doi: 10.1007/978-3-03037734-2_60

56. VideoAnt service. (2019). Retrieved from https://ant.umn.edu/

57. Whitley-Grassi N., Baizer J.S. (2010). Video lecture capture in physiology courses: Student attendance, video viewing and correlations to course performance. International Journal of Instructional Technology and Distance Learning, 7(10), 31-38. Retrieved from http://www.itdl.org/Journal/Oct_10/article04.htm

58. Willis D. (1983a). The potential and limitations of video. In Video Applications in English Language Teaching. London: Pergamon Press in association with the British Council, 17-27. Retrieved from https://www.teachingenglish.org.uk/sites/teacheng/files/F044\%20ELT49\%20Video\%20Applications\%20in\%20English\%20Language\%20Teaching_v3.pdf\#page $=28$

59. Willis J. (1983b). The Role of the visual element in spoken discourse: Implications for the exploitation of video in the EFL classroom. In Video Applications in English Language Teaching. 
London: Pergamon Press in association with the British Council, 29-43. Retrieved from https://www.teachingenglish.org.uk/sites/teacheng/files/F044\%20ELT-

49\%20Video\%20Applications\%20in\%20English\%20Language\%20Teaching_v3.pdf\#page $=40$

60. Woottipong K. (2014). Effect of using video materials in the teaching of listening skills for university students. International Journal of Linguistics, 6(4), 200-212. doi: 10.5296/ijl.v6i4.5870

61. Yuksel D., Tanriverdi B. (2009). Effects of watching captioned movie clip on vocabulary development of EFL learners. The Turkish On-Line Journal of Educational Technology, 8(2), 48-54. Retrieved from http://www.tojet.net/volumes/v8i2.pdf\#page=49

62. Zanón N.T. (2006). Using subtitles to enhance foreign language learning. Porta Linguarum, 6, 41-52. Retrieved from https://dialnet.unirioja.es/servlet/articulo?codigo $=2371555$

63. Zhu Y., Song Y., Li X., Liu Q., Li H. (2015). Research on networked video courseware system based on object-oriented method. In the Proceedings of the IEEE International Conference on Software Engineering and Service Sciences (ICSESS2015), 6. Piscataway, New Jersey: IEEE Press, 525-528.

64. Zhubanova Sh.A., Tukhtabayeva A.S. (2017). Developing auditory and visual skills through multimedia technologies. In Bulletin Abay Kazakh National Pedagogical University. Retrieved from https://articlekz.com/en/article/19411 